\title{
THE FEKETE-SZEGÖ FUNCTIONAL PROBLEMS FOR SOME SUBCLASSES OF $m$-FOLD SYMMETRIC BI-UNIVALENT FUNCTIONS
}

\author{
Huo Tang, H. M. Srivastava, S. Sivasubramanian And P. Gurusamy
}

Abstract. In this paper, we introduce several new subclasses of the class of $m$-fold symmetric bi-univalent functions and obtain estimates of the Taylor-Maclaurin coefficients $\left|a_{m+1}\right|,\left|a_{2 m+1}\right|$ and Fekete-Szegö functional problems for functions in these new subclasses. The results presented in this paper improve the earlier results of Ali et al. [1], Frasin and Aouf [6], and Srivastava et al. [14] in terms of the bounds as well as the ranges of the parameter under consideration. Our results also further generalize the results of Peng et al. [19].

Mathematics subject classification (2010): Primary 30C45, 33C50; Secondary 30C80.

Keywords and phrases: Analytic functions, Fekete-Szegö functional problems, Bi-univalent functions, Taylor-Maclaurin coefficients, $m$-fold symmetric functions, subordination.

\section{REFERENCES}

[1] R. M. Ali, S. K. Lee, V. Ravichandran and S. Subramanian, Coefficient estimates for biunivalent Ma-Minda starlike and convex functions, Appl. Math. Lett. 25 (2012), 344-351.

[2] M. K. Aouf, J. SoKól AND J. Dziok, On a subclass of strongly starlike functions, Appl. Math. Lett. 24 (2011), 27-32.

[3] D. A. Brannan And J. G. Clunie (Editors), Aspects of Contemporary Complex Analysis, Proceedings of the NATO Advanced Study Institute (University of Durham, Durham; July 1-20, 1979), Academic Press, New York and London, 1980.

[4] D. A. BRAnNAn And T. S. TAHA, On some classes of bi-univalent functions, in Mathematical Analysis and Its Applications (S. M. Mazhar, A. Hamoui and N. S. Faour, Editors) (Kuwait; February 18-21, 1985), KFAS Proceedings Series, Vol. 3, Pergamon Press (Elsevier Science Limited), Oxford, 1988, pp. 53-60; see also Studia Univ. Babeş-Bolyai Math. 31 (2) (1986), 70-77.

[5] P. L. Duren, Univalent Functions, Grundlehren der Mathematischen Wissenschaften, Band 259, Springer-Verlag, New York, Berlin, Heidelberg and Tokyo, 1983.

[6] B. A. Frasin And M. K. Aouf, New subclasses of bi-univalent functions, Appl. Math. Lett. 24 (2011), 1569-1573.

[7] M. Lewin, On a coefficient problem for bi-univalent functions, Proc. Amer. Math. Soc. 18 (1967), 63-68.

[8] W. C. MA AND D. Minda, A unified treatment of some special classes of unvalent functions, in Proceedings of the Conference on Complex Analysis (Tianjin; June 19-23, 1992) (Zhong Li, Fuyao Ren, Lo Yang and Shunyan Zhang, Editors), Conference Proceedings and Lecture Notes in Analysis, Vol. I, International Press, Cambridge, Massachusetts, 1994, pp. 157-169.

[9] Ch. Pommerenke, On the coefficients of close-to-convex functions, Michigan. Math. J. 9 (1962), 259-269.

[10] J. SoKóL, On a condition for $\alpha$-starlikeness, J. Math. Anal. Appl. 352 (2009), 696-701.

[11] J. SoKóL, A certain class of starlike functions, Comput. Math. Appl. 62 (2011), 611-619.

[12] H. M. SRIVASTAVA AND D. BANSAL, Coefficient estimates for a subclass of analytic and bi-univalent functions, J. Egyptian Math. Soc. 23 (2015), 242-246.

[13] H. M. Srivastava, S. Bulut, M. ÇAglar and N. YaĞmur, Coefficient estimates for a general subclass of analytic and bi-univalent functions, Filomat 27 (2013), 831-842. 
[14] H. M. Srivastava, A. K. Mishra and P. Gochhayat, Certain subclasses of analytic and biunivalent functions, Appl. Math. Lett. 23 (2010), 1188-1192.

[15] H. M. Srivastava, N. Tuneski And E. Georgieva-Celakoska, Some distortion and other properties associated with a family of $n$-fold symmetric Koebe type functions, Austral. J. Math. Anal. Appl. 9 (2) (2012), Article 1, 1-17.

[16] Q.-H. XU, Y.-C. GUI AND H. M. SRIVAStaVA, Coefficient estimates for a certain subclass of analytic and bi-univalent functions, Appl. Math. Lett. 25 (2012), 990-994.

[17] Q.-H. XU, H. M. SRIVASTAVA AND Z. LI, A certain subclass of analytic and close-to-convex functions, Appl. Math. Lett. 24 (2011), 396-401.

[18] Q.-H. XU, H.-G. XIAO AND H. M. SRIVASTAVA, A certain general subclass of analytic and biunivalent functions and associated coefficient estimate problems, Appl. Math. Comput. 218 (2012), 11461-11465.

[19] Z.-G. Peng AND Q.-Q. Han, On the coefficients of several classes of bi-uivalent functions, Acta. Math. Sci. Ser. B Engl. Ed. 34 (2014), 228-240.

[20] H. TAng, G.-T. Deng And S.-H. LI, Coefficient estimates for new subclasses of Ma-Minda biunivalent functions, J. Inequal. Appl. 2013 (2013), Article ID 317, 1-10. 